\title{
Assessing the impact of hydrodynamics on large-scale flood wave propagation - a case study for the Amazon Basin
}

\author{
Jannis M. Hoch ${ }^{1,2}$, Arjen V. Haag ${ }^{2}$, Arthur van Dam ${ }^{2}$, Hessel C. Winsemius ${ }^{2}$, Ludovicus P. H. van Beek ${ }^{1}$, and \\ Marc F. P. Bierkens ${ }^{1,2}$ \\ ${ }^{1}$ Department of Physical Geography, Utrecht University, P.O. Box 80115, 3508 TC Utrecht, the Netherlands \\ ${ }^{2}$ Deltares, P.O. Box 177, 2600 MH Delft, the Netherlands \\ Correspondence to: Jannis M. Hoch (j.m.hoch@uu.nl)
}

Received: 26 August 2016 - Published in Hydrol. Earth Syst. Sci. Discuss.: 29 August 2016

Revised: 16 December 2016 - Accepted: 20 December 2016 - Published: 9 January 2017

\begin{abstract}
Large-scale flood events often show spatial correlation in neighbouring basins, and thus can affect adjacent basins simultaneously, as well as result in superposition of different flood peaks. Such flood events therefore need to be addressed with large-scale modelling approaches to capture these processes. Many approaches currently in place are based on either a hydrologic or a hydrodynamic model. However, the resulting lack of interaction between hydrology and hydrodynamics, for instance, by implementing groundwater infiltration on inundated floodplains, can hamper modelled inundation and discharge results where such interactions are important. In this study, the global hydrologic model PCR-GLOBWB at 30 arcmin spatial resolution was one-directionally and spatially coupled with the hydrodynamic model Delft 3D Flexible Mesh (FM) for the Amazon River basin at a grid-by-grid basis and at a daily time step. The use of a flexible unstructured mesh allows for fine-scale representation of channels and floodplains, while preserving a coarser spatial resolution for less floodprone areas, thus not unnecessarily increasing computational costs. In addition, we assessed the difference between a 1-D channel/2-D floodplain and a 2-D schematization in Delft 3D FM. Validating modelled discharge results shows that coupling PCR-GLOBWB to a hydrodynamic routing scheme generally increases model performance compared to using a hydrodynamic or hydrologic model only for all validation parameters applied. Closer examination shows that the 1-D/2-D schematization outperforms 2-D for $r^{2}$ and root mean square error (RMSE) whilst having a lower KlingGupta efficiency (KGE). We also found that spatial coupling has the significant advantage of a better representation of in-
\end{abstract}

undation at smaller streams throughout the model domain. A validation of simulated inundation extent revealed that only those set-ups incorporating 1-D channels are capable of representing inundations for reaches below the spatial resolution of the 2-D mesh. Implementing 1-D channels is therefore particularly of advantage for large-scale inundation models, as they are often built upon remotely sensed surface elevation data which often enclose a strong vertical bias, hampering downstream connectivity. Since only a one-directional coupling approach was tested, and therefore important feedback processes are not incorporated, simulated discharge and inundation extent for both coupled set-ups is generally overpredicted. Hence, it will be the subsequent step to extend it to a two-directional coupling scheme to obtain a closed feedback loop between hydrologic and hydrodynamic processes. The current findings demonstrating the potential of one-directionally and spatially coupled models to obtain improved discharge estimates form an important step towards a large-scale inundation model with a full dynamic coupling between hydrology and hydrodynamics.

\section{Introduction}

Global flood risk is increasing at an accelerating rate due to a combination of changed climatic conditions and intensified urbanization in proximity to rivers (Ceola et al., 2014; Hirabayashi et al., 2013; Jongman et al., 2012; Winsemius et al., 2016). This is reflected by a significant increase in economic losses in the latter half of the 20th century associated with flooding. In 2012 alone, economic losses ex- 
ceeded USD 19 billion, comprising one-third of all losses due to natural hazards (Munich Re, 2010; UNISDR, 2011; Visser et al., 2012). To better understand current and future hazards and risks, and to facilitate robust climate change adaption and mitigation measures, this study aims to show the strengths, weaknesses, and opportunities of spatially coupled hydrologic-hydrodynamic models compared to mere hydrologic and hydrodynamic models, respectively. We believe that coupling models is a pivotal cornerstone for more realistic, robust, and integrated flood hazard and risk assessments.

Recently, modelling flood hazards and risks experienced a boost in attention as flood hazard maps are paramount for sound flood risk assessments (Hagen and Lu, 2011). In many cases, however, flood hazard maps are computed for geographically limited areas only. Because flood waves show strong spatial correlation in different but neighbouring basins, they can be considered to be large-scale phenomena, and, in turn, demand large-scale modelling approaches (Jongman et al., 2014), especially over data-scarce areas (Ward et al., 2015). The outcome of such large-scale models may be beneficial for global stakeholders as the United Nations Office for Disaster Risk Reduction (UNISDR) or the World Bank, for instance, to facilitate discussions with stakeholders' risks, better allocate their funding, but also for re-insurance companies or governmental entities (Ward et al., 2015). Tiling small-scale maps from different smallscale studies to obtain the required large-scale estimates is not a viable alternative, as it introduces many sources of uncertainty and inconsistencies (Pappenberger et al., 2006, 2012) and does not account for any spatio-temporal correlation. Recent studies aimed to model large-scale flood hazard by dividing the model domain into various catchments (Alfieri et al., 2014; Dottori et al., 2016; Sampson et al., 2015). Notwithstanding the promising results, such approaches still require upstream boundary forcing, additional efforts due to division and merging, and still cannot fully account for the aforementioned spatial correlation of flood events in neighbouring basins, as they use synthetic flood events.

Triggered by an increase in computational capacities and in availability of remotely sensed data for parameterization, calibration, and validation, research on large-scale inundation modelling was intensified in past years. For example, a range of global data sets is by now freely available such as, inter alia, digital elevation maps (DEMs) (e.g. HydroSHEDS, Lehner et al., 2008; ASTER; GTOPO30), water body maps (e.g. G3WBM, Yamazaki et al., 2015), global river width and depth (Andreadis et al., 2013), or observed river discharge (Global River Discharge Centre - GRDC; Global River Discharge Project - RivDIS). In addition, algorithms to compute river widths globally (Yamazaki et al., 2014), to quantitatively describe topography (height above nearest drainage - HAND, Rennó et al., 2008), or to apply surface reconditioning (Yamazaki et al., 2012a) were presented.

With these data sets and algorithms being available, largescale flood hazard modelling approaches are strongly facili- tated. Most of the approaches can be categorized by (a) the processes represented and (b) the model schematization. While the latter category comprises possible schematizations such as 2-D grids, 1-D channels, or coupled 1-D/2-D models, the first contains the possibility to include or exclude several hydrologic or hydrodynamic models or their components in the computational backbone.

Global hydrologic models (GHMs), such as PCRGLOBWB (van Beek and Bierkens, 2008), WaterGAP (Döll et al., 2003), or the variable infiltration capacity (VIC) model (Liang et al., 1994; Wood et al., 1992), are capable of modelling water balances, and hence available surface water volumes, at the global scale. Another advantage is that hydrologic models can easily be forced with ensembles of global climate models (GCMs), which is beneficial for predictions of future changes in flood hazard and risk (Hirabayashi et al., 2013; Jongman et al., 2014; Weiland et al., 2010; Winsemius et al., 2016). However, large-scale hydrologic models strongly depend on the quality of their input data and robustness of their process descriptions, which may differ remarkably between individual catchments (Kling et al., 2015; Li et al., 2015). Besides, many GHMs are relatively coarse scale, with the finest spatial resolution for global models currently being 5 arcmin or $10 \mathrm{~km} \times 10 \mathrm{~km}$ at the Equator (Bierkens, 2015). Although sub-grid post-processing can be used to meliorate outcomes as done, for instance, in the "Global Flood Risk with IMAGE Scenarios (GLOFRIS)" framework by Winsemius et al. (2013), this may reduce model accuracy, since important floodplain properties and channel-floodplain dynamics can only be implemented in a simplistic manner.

Dedicated hydrodynamic models, on the other hand, put their emphasis on the correct simulation of surface water flow and levels, and hence consider important factors such as inertia terms of channel geometry, in more detail than most large-scale hydrologic models, as the latter often employ kinematic wave or Muskingum-Cunge approaches only. Thus, hydrodynamic models allow for simulating backwater effects which are pivotal flood-triggering processes (Moussa and Bocquillon, 1996; Paiva et al., 2013). Hydrodynamic models are usually forced with upstream boundary conditions based on regionalization of observation stations (Huang et al., 2014; Sampson et al., 2015; Wilson et al., 2007). Yet, using observed boundary conditions makes them highly dependent on the presence and spacing of the stations. The aforementioned spatial correlation of flood waves can thus not realistically be modelled, as important spatially distributed flood-triggering processes such as precipitation events over large surface areas would not necessarily be captured by the stations (for instance, the El Niño-Southern Oscillation (ENSO) phenomenon in the Amazon River basin) (Molinier et al., 2009).

Most hydrodynamic modelling approaches are implemented by employing 1-D, 2-D, or 1-D/2-D schematizations. Mere 1-D models, however, have difficulties with modelling surface flow over larger areas and floodplains specifically, 
while regular 2-D models inevitably lead to an increase in required computational power, especially if results need to be computed at a fine spatial resolution (Finaud-Guyot et al., 2011; Liu et al., 2015). In addition, 2-D models experience problems in case the actual river width is smaller than the grid size and also in case there are multiple rivers within one cell, although it is possible to partly overcome that by applying sub-gridding routines (Neal et al., 2012). Besides, flow resistance to surface roughness is overestimated in 2-D setups. In addition to the currently employed techniques, use of flexible meshes is emerging, which allows for both a fine spatial resolution in more relevant areas while at the same time not unnecessarily increasing computational costs where only limited dynamics and changes are expected. Such flexible gridding over the model domain may moreover be a viable avenue to meet the debated grand challenge of hyperresolution modelling (Bierkens et al., 2015; Wood et al., 2011). Yet, the application of flexible meshes focussed so far mostly on oceanic and coastal computations (Chen et al., 2003; Muis et al., 2016) and less on the representation of rivers and floodplains, although studies corroborate its high potential (Castro Gama et al., 2013).

Based on this, a call for a more holistic large-scale modelling approach can be formulated. Coupling existing models may provide an advantageous way forward as the strengths of individual models are maintained and weaknesses compensated. In fact, many studies already integrate various disciplines by model coupling, for instance, hydrologic with atmospheric models (e.g. Senatore et al., 2015; Wagner et al., 2016), climate models (e.g. Butts et al., 2014; Zabel and Mauser, 2013), or glacier models (e.g. Naz et al., 2014; Zhao et al., 2013). To obtain information about inundation patterns, approaches to couple hydrology with hydrodynamics were already explored in previous studies, but either at the sub-catchment scale only (Paiva et al., 2013; Rudorff et al., 2014a, b); by using a land surface model (LSM) to obtain input (Pappenberger et al., 2012); by employing the hydrologic model VIC (Liang et al., 1994; Wood et al., 1992) to compute boundary discharge for LISFLOOD-FP (Bates and de Roo, 2000) in the Lower Zambezi River (Schumann et al., 2013); by using output from a hydrologic model as lateral inflow for LISFLOOD-FP to model inundation dynamics in the Ob River (Biancamaria et al., 2009); or by using used output from GloFAS (Global Flood Awareness System) (Alfieri et al., 2013) with hydrodynamics to obtain synthesized floods with different return periods (Dottori et al., 2016). Notwithstanding the contributions of these studies to current flood risk understanding, they still lack the capability to produce hydrological forcing within the actual model domain, and are thus not able to simulate the feedback between hydrology and inundation processes on floodplains.

In the present study, we present a one-directional and spatially explicit coupling approach between the global hydrologic model PCR-GLOBWB and the state-of-the-art hydrodynamic model Delft 3D Flexible Mesh, allowing for the ex- change of information throughout the entire model domain. To our knowledge, this is a novelty in large-scale inundation modelling. Moreover, the exchange of variables between hydrology and hydrodynamics takes place on a grid-to-grid basis at the time-step or even sub-time-step level. This approach allows for online coupling, thus providing the potential to eventually perform two-directional exchange of information. The Amazon River basin was schematized with both a 2-D flexible mesh and a 1-D/2-D set-up, allowing us to test potential (dis)advantages between both set-ups. Additionally, the hydrologic and hydrodynamic models were also run in a stand-alone mode to fully assess the added value of model coupling. The utilization of only global data sets and algorithms ensures transferability to other basins as well as a straightforward scalability of our approach to larger scales. It is moreover a part of the study's aim to detect the most suitable model set-ups to continue with future extensions and larger-scale applications of our coupling technique.

With our approach, we are confident in our ability to close the gap between hydrology and hydrodynamics, and to make a step towards a global, fully fledged inundation model. Such a model set-up can provide information on spatial correlations and interrelations between flood events, ultimately facilitating current large-scale flood hazard and risk assessments. Eventually, this can be used for the formulation of more robust climate change adaption and mitigation measures, and to further inform global flood risk policies.

\section{Methodology}

The two models used for this study are the global hydrologic model PCR-GLOBWB (van Beek, 2008; van Beek et al., 2011), and the state-of-the-art hydrodynamic model Delft 3D Flexible Mesh (FM) (Deltares, 2016; Kernkamp et al., 2011). To test the added value of our coupling approach as well as the differences between 2-D and 1-D/2-D schematization, the following experimental set-up was designed, consisting of five modelling runs: (i) PCR-GLOBWB with its DynRout extension to obtain purely hydrology-based results; (ii) a 2D and (iii) 1-D/2-D Delft 3D FM schematization both forced with discharge observed at GRDC stations to obtain purely hydrodynamic-based results; (iv) and (v) the same two FM schematizations forced with output from PCR-GLOBWB. For all runs with Delft 3D FM, a constant water level of $0.0 \mathrm{~m}$ is assumed at the river mouth as a downstream boundary. Even though the influence of ocean tides is reported to be significant (Lima et al., 2003), tidal dynamics were not considered in the present study, as this exceeds the scope of the work.

Each set-up was applied for the Amazon Basin for the period from 1 January 1985 to 31 December 1990. This early period had to be chosen, as for some GRDC stations no more recent discharge data are available. Output of all cases was validated against observed GRDC discharge data at Óbidos 
(GRDC station no. 3629000), the most downstream GRDC station available (Fig. 1). To this end, three functions were applied for validation: the coefficient of determination $\left(r^{2}\right)$ to assess the reproduction of the shape of the hydrograph, the root mean squared error (RMSE) to assess the water balance, and the Kling-Gupta efficiency (KGE) (Gupta et al., 2009) to evaluate the model's skill. In addition, we qualitatively inspected the inundation extent and water levels for the various model runs. We employed LandSat imagery taken on 1 July 1989 to validate simulated inundation extent, as it is one of the few cloud-free images at this time, and represents inundation patterns during peak season. To compare simulated water levels, four observation points on floodplains along the main river reach were defined (Fig. 1): "Loc1" close to the delta $\left(1.62^{\circ} \mathrm{S}, 52.46^{\circ} \mathrm{W}\right)$; "Loc2" downstream of Óbidos $\left(2.15^{\circ} \mathrm{S}, 54.55^{\circ} \mathrm{W}\right)$; "Loc3" just upstream of Óbidos $\left(2.45^{\circ} \mathrm{S}, 56.81^{\circ} \mathrm{W}\right)$; "Loc4" even further upstream $\left(2.97^{\circ} \mathrm{S}\right.$, $\left.58.35^{\circ} \mathrm{W}\right)$.

\subsection{The hydrologic model: PCR-GLOBWB}

To generate hydrologic input, the global hydrologic model PCR-GLOBWB at 30 arcmin resolution (approximately $55 \mathrm{~km} \times 55 \mathrm{~km}$ at the Equator) was applied. It is entirely coded in PCRaster Python (Karssenberg et al., 2010). PCRGLOBWB distinguishes between two vertically stacked soil layers, an underlying groundwater layer, and a surface canopy layer. Water can be exchanged vertically, and excess surface water can be routed horizontally along a local drainage direction (LDD) network. In the present study, the kinematic wave approach was used for routing, and Manning's surface roughness coefficient was uniformly set to $0.03 \mathrm{~s} \mathrm{~m}^{-1 / 3}$. This value is in line with other studies in the Amazon Basin (Paiva et al., 2013; Rudorff et al., 2014a, b; Trigg et al., 2009; Yamazaki et al., 2011). A uniform value was chosen to eliminate this factor as a cause for differences when comparing the stand-alone runs as well as 1D/2-D set-ups. The model was forced with Climate Research Unit (CRU) precipitation and temperature data (Harris et al., 2014), and evaporation was computed using the PenmanMonteith equation. Data sets were downscaled to daily fields for the period from 1957 to 2010 using ERA40/ERAI (Kållberg et al., 2005; Uppala et al., 2005). For more information on PCR-GLOBWB, we refer to van Beek and Bierkens (2008) and van Beek et al. (2011). PCR-GLOBWB was already applied in various studies: Weiland et al. (2010) investigated how forcing from different global circulation models can reproduce global discharge variability; Yossef et al. (2012) concluded that PCR-GLOBWB shows skill when used for flood forecasting; Wanders and Wada (2015) employed the model to assess the impact of humans and climate on drought in the 21 st century; de Graaf et al. (2015) fully coupled PCR-GLOBWB with a physically based groundwater model capable of simulating lateral flows.

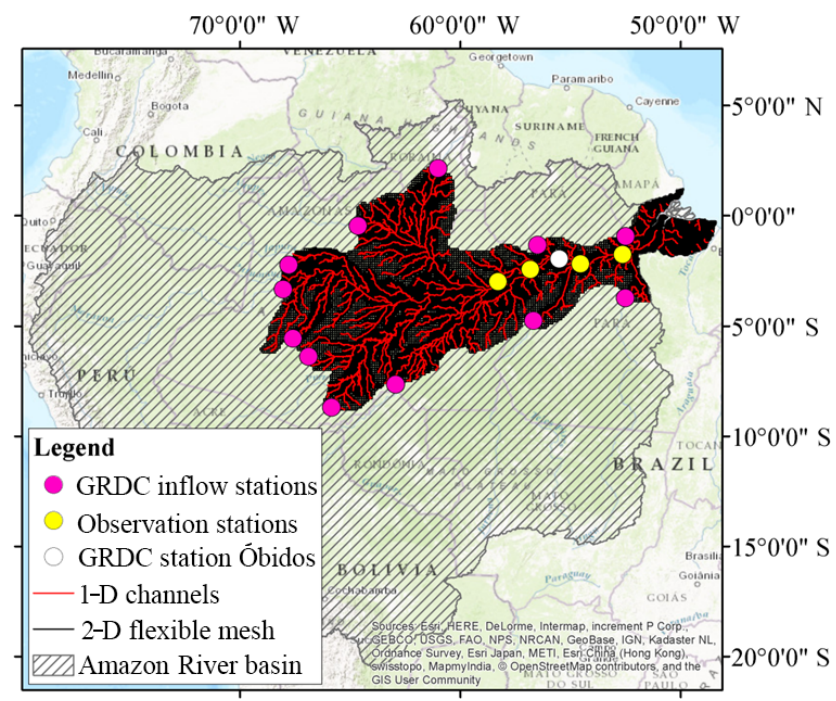

Figure 1. Map of the extent of 2-D grid and 1-D channels as part of entire Amazon River basin; additionally shown are the water level observation stations 1-4 counting from delta to upstream, as well as GRDC station Óbidos for discharge measurements and all GRDC input stations.

From a priori runs, we were informed that PCR-GLOBWB underestimates discharge in the Amazon Basin. To eventually obtain discharge values that are close to observed values and enhance the significance of the validation procedure, we therefore decided to apply a simplistic regional optimization technique for five model parameters. To this end, we tested the model's performance sensitivity to a range of multipliers for these parameters, using the log-scaled Nash-Sutcliffe coefficient of simulated discharge at Óbidos as a performance indicator. Based on performance, we then chose the combination of multipliers resulting in the highest log-scaled NashSutcliffe coefficient. Consequently, the minimum soil depth fraction for which interflow is calculated, the log-scaled saturated hydraulic conductivity of groundwater flow $\left(k_{\text {sat }}\right)$, and the log-scaled recession coefficient were multiplied by 0.5 . The general parameterization of PCR-GLOBWB, however, remained unaffected and no further local calibration was performed to preserve the global applicability of the model. PCR-GLOBWB also has the option to include human water use from irrigation, households, and industry as an integral part of its model runs. In our application, however, we decided to simulate river discharge under natural flow conditions.

\subsection{The hydrodynamic model: Delft 3D Flexible Mesh}

For hydrodynamic calculations, the state-of-the-art model Delft 3D FM was employed (Kernkamp et al., 2011). It allows the user to schematize the model domain with a flexible mesh in 1-D/2-D/3-D, and therefore supports the computationally efficient schematization of topographically chal- 


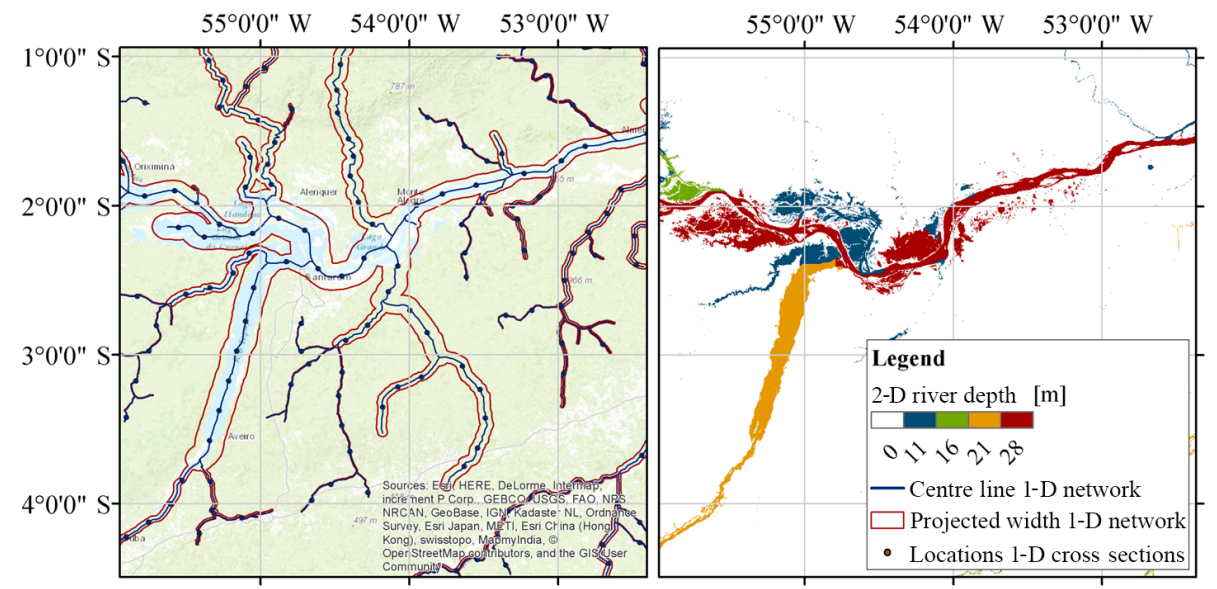

Figure 2. The 1-D network centre line and cross sections, as well as its computed (projected) width and computed river depth for all cells defined as permanent water bodies in G3WBM for the same details.

lenging areas such as river bends or irregular slopes. The model solves the full Saint-Venant equations, or shallowwater equations (SWEs). Solving the SWEs is, as stated before, a major advantage compared to most large-scale hydrodynamic and hydrologic models because this is essential to account for important flood-triggering processes such as back-water effects (Moussa and Bocquillon, 1996; Paiva et al., 2013). In analogy to PCR-GLOBWB, the surface roughness coefficient was set to $0.03 \mathrm{~s} \mathrm{~m}^{-1 / 3}$ to guarantee comparability. We expressly desisted from calibrating model parameters for any of our hydraulic model set-ups due to two reasons. First, calibration may obscure the actual performance of the model set-ups with respect to real governing hydraulic processes as their quality may possibly be governed by calibration. Second, we aim to apply the presented coupling scheme at other basins. Locally calibrating FM for the Amazon Basin may introduce inconsistencies among the global data sets used for model set-up, and jeopardize their validity for ungauged basins.

Due to its very recent publication, only a limited number of published studies using Delft 3D FM are available. It was, for instance, applied in a global-scale reanalysis for extreme sea levels (Muis et al., 2016). In another study, Castro Gama et al. (2013) applied Delft 3D FM successfully to model flood hazard at the Yellow River and concluded that applying a flexible mesh reduces computation time by a factor of 10 compared to square grids with equal quality of model output.

\subsection{Defining the 1-D network}

The course of the 1-D river channels as well as effective river width $w$ were derived based on the Global Width Database for Large Rivers (GWD-LR) algorithm by Yamazaki et al. (2014), hence already accounting for river braiding and islands. Comparing both the course and the computed width of the obtained 1-D network schematization with OpenStreetMaps (OSM) yielded an overall good fit with lower goodness of fit in meandering and delta regions (Fig. 2).

River depth $d(\mathrm{~m})$ was subsequently estimated from river width $w(\mathrm{~m})$ by combining the following equations from Paiva et al. (2011), with $A_{d}\left(\mathrm{~km}^{2}\right)$ being the upstream area of one point along the river:

$w=0.81 A_{d}^{0.53}$

$d=1.44 A_{d}^{0.19}$

to the following width-depth relation:

$d=1.55 w^{0.36}$.

Benchmarking the resulting river depths obtained with Eq. (3) with those found in a global river bankfull width and depth database by Andreadis et al. (2013) showed better results than those obtained with the widely used widthdepth relation proposed by Leopold and Maddock (1953). By means of the aforementioned equations, a maximum depth of $54 \mathrm{~m}$, a minimum depth of $5 \mathrm{~m}$, and an average depth of $13 \mathrm{~m}$ were computed. Finally, width and depth information was stored in cross sections along the network with a spacing of around $20 \mathrm{~km}$ (Fig. 2). We are confident that applying a hydro-geomorphic relation between river depth and observed width, as also applied by Neal et al. (2012), is valid in this case due to three reasons. First, the equations were constructed based on a large sample of cross-section information, and thus can be extrapolated over larger areas of application. Second, we consider the width information of GWD-LR to reflect local conditions better than the more onedimensional approach of relating bathymetric information on only one predicting variable such as upstream area or discharge. Last, bathymetric information is internally interpolated in the model, preventing any extreme local variations 
in observed river width and depth, consequently also avoiding improbable local flow hindrance.

\subsection{Defining the 2-D flexible mesh}

For surface elevation values, we used the HydroSHEDS data set, which was derived from the Shuttle Radar Topography Mission (SRTM) (Lehner et al., 2008). Because significant vertical measurement errors emanate from the C-band synthetic aperture radar (SAR) used by SRTM, extensive hydrologic conditioning was carried out in this study to remediate the most relevant errors in currently available data sets.

First, noise by vegetation cover was reduced. This is essential as the radar signal cannot fully penetrate dense canopy, leading to quality degradation especially in rainforests (Berry et al., 2007). As a result, absolute vertical errors of around $22 \mathrm{~m}$ were found in the Amazon Basin (Carabajal and Harding, 2006; Sanders, 2007). The approach used in the present study to account for vegetation cover is described in detail by Baugh et al. (2013). For the present study, $50 \%$ of the canopy heights reported by Simard et al. (2011) were subtracted from original elevation values, as proposed by Baugh et al. (2013).

Even after vegetation was removed, flow connectivity can be hindered by grid cells surrounded by higher elevated cells which can stem from elevation irregularities such as islands, bridges, or other residues. Thus, these local depressions were removed in a second step to guarantee downstream flow connectivity along flow paths. Conventional procedures, such as lifting downstream cells or stream burning, fail, however, to adequately address this issue as the land surface is altered to be one-sided, and thus should not be applied to rivers in flat environments such as the Amazon River (Getirana et al., 2009). Hence, a more advanced algorithm based on the work of Yamazaki et al. (2012b) was applied. This algorithm either "digs" or "fills" along a flow path, as defined by the HydroSHEDS LDD, resulting in smoothed elevation values along downstream flow paths as demonstrated for two flow paths in Fig. 3.

While, for 1-D/2-D applications, the 1-D vector channel data are embedded into the smoothed 2-D elevation, it was necessary to compute bathymetric information for the 2-D schematizations. This is because the DEM used lacks reliable information about river bathymetry as the SRTM radar signal is not able to fully penetrate deeper water bodies. To derive bathymetry information, current research projects aim to exploit available remotely sensed data or aerial photography (Kinzel et al., 2013; Legleiter, 2015, 2016; Yoon et al., 2012). Yet, obtaining satisfactory information for largescale river bathymetry remains a major research challenge. For the present study, river depth $d$ was computed as a function of upstream area $A_{d}$ as follows: for all grid cells where $A_{d} \geq 10^{4} \mathrm{~km}^{2}$, Eq. (2) was applied to compute $d$ on a gridby-grid basis. The threshold of $10^{4} \mathrm{~km}^{2}$ was chosen after trial and error to filter many small and short reaches which were not represented by the 1-D network. Due to the differences in the 1-D vector network and LDD map used for the 2-D raster data, it was, however, not possible to precisely apply the same equations. Despite these minor differences in methodology, manual inspection of computed river depths, computed for 1-D channels and 2-D bathymetry, revealed no major discrepancies in our model domain, and we therefore consider both ways to compute bathymetry valid, particularly in light of the limited availability of bathymetry data for large-scale applications. The computed depth of one specific pixel was then spread to all cells whose distance is shortest to the pixel under consideration. Subsequently, the resulting bathymetry map was created by lowering elevation values of only those pixels defined as permanent water bodies in the Global 3-second Water Body Map (G3WBM) developed by Yamazaki et al. (2015) (see Fig. 2). The computed elevation values were subsequently interpolated over the flexible mesh, and elevation values per FM cell are obtained by unweighted spatial averaging of the computed elevations at the cell vertices.

Since the hydrodynamic computations and model coupling still require significant computational power for multiyear simulations, the modelling domain of Delft 3D FM was limited to flood-prone areas. To derive a suitable extent, the height above nearest drainage (HAND) algorithm was applied (Rennó et al., 2008), as it yields relative terrain elevation to the nearest hydrologically connected drainage. The flexible mesh was then obtained by automatic local grid refinement of a coarser regular grid based on the obtained HAND values and limiting it to grids where computed HAND values are less than or equal to $25 \mathrm{~m}$; that is, until terrain reached an elevation of $25 \mathrm{~m}$ above the nearest water body. The final model domain is presented in Fig. 1 and still encompasses an area of around $1.2 \times 10^{6} \mathrm{~km}^{2}$, which is nearly a fifth of the entire Amazon River basin. The threshold was chosen arbitrarily but model results showed that it is sufficiently large. By establishing the refinement on this algorithm, the flexible mesh has the finest spatial resolution $(2.5 \mathrm{~km} \times 2.5 \mathrm{~km})$ for areas with lowest HAND values, such as water bodies and floodplains, while areas with higher HAND values, and hence areas more remote from water bodies, are modelled with coarser spatial resolution up to $10 \mathrm{~km} \times 10 \mathrm{~km}$ per grid. In these latter regions, the number of grid cells is thus reduced by a factor of 16 , benefitting the stability-limited computational time step and significantly reducing overall computation times.

\subsection{Coupling the models}

Coupling PCR-GLOBWB with Delft 3D FM was achieved by means of the basic model interface (BMI). Peckham et al. (2013) proposed the BMI as a tool within the Community Surface Dynamics Modeling System (CSDMS) project to exchange information between separate models at any given time step. By exposing certain internal state variables of the 

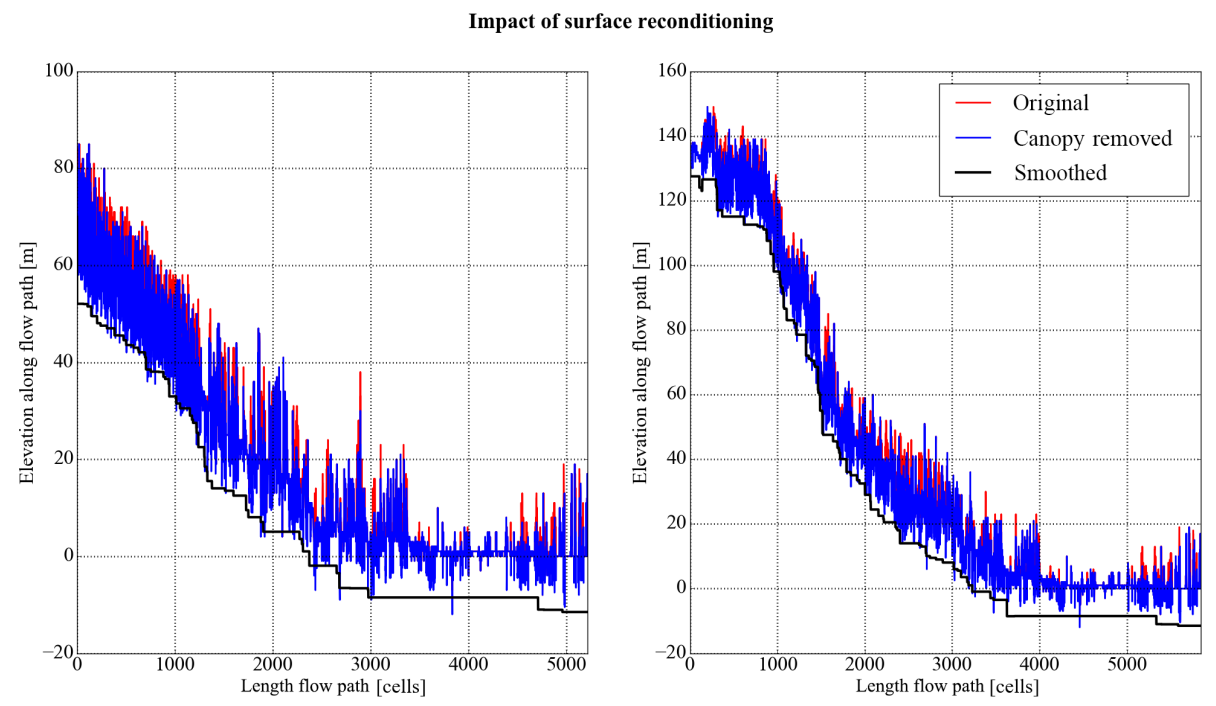

Figure 3. Impact of vegetation removal (canopy removed) and surface reconditioning (smoothed) on surface elevation along two exemplary flow paths compared to original HydroSHEDS-DEM data (original).

model by means of the BMI, interactive modelling is facilitated, as these variables can be modified during the model execution.

Generally, each BMI has several functions that can be called from external applications like, as in this case, a Python script. First, models need to be initialized. Second, the BMI enables the user to retrieve variables, and to manipulate them if required, for instance, to convert units or to add values. Third, the manipulated variables can be set back to the original model or can be used to overwrite variables in one or multiple other models, given that they agree to the internal data structure of those models. Fourth, models connected to a BMI can be updated at a user-specified time step. This way, it is possible to get, change, and set variables during the execution of the models in use. In a last step, models can be finalized to end the computations. It has to be noted that for each model involved, one specific BMI adapter has to be developed with respect to the specific internal model structure and programming language. Whilst PCR-GLOBWB is already in Python and its BMI implementation is hence straightforward, Delft 3D FM offers a native $\mathrm{C}$-compliant BMI implementation which can be called from within Python using the BMI Python package (see https://github.com/openearth/bmi-python). For further information on the BMI, refer to Peckham et al. (2013) and the related website (CSDMS, 2016).

In order to be able to spatially couple both models, it is required to overlay the model extent of both FM and PCRGLOBWB. To this end, the centroid of each 2-D FM cell was computed, and a FM cell is then considered to be coupled to PCR-GLOBWB if its centroid is located within the bounds of the PCR cell. The coupling algorithm (Fig. 4) was employed at a daily time step: first, PCR-GLOBWB was run for 1 day;

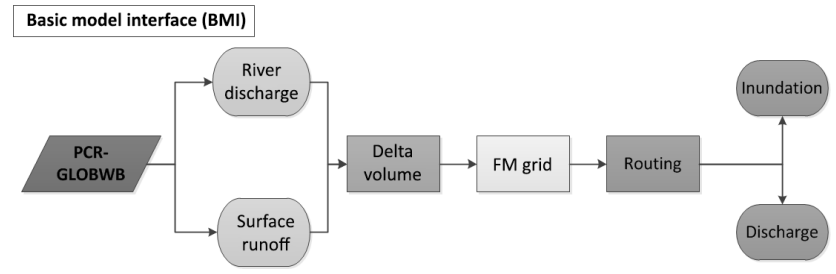

Figure 4. Flow diagram of coupling process steps embedded in the BMI.

then, a daily delta volume (that is, the volume to be added to FM with the day's time step) was computed for every coupled PCR cell as the sum of daily river discharge inflows at the boundary of FM and local surface runoff throughout the model domain. The daily delta volume was subsequently divided over and added to all FM cells within this specific PCR cell. Note that this explicit spatial forcing of Delft 3D FM is fundamentally different from the GRDC-fed runs, where only upstream discharge boundary conditions are applied, and no spatially distributed forcing is active. As only the most downstream part of the Amazon Basin is schematized in FM, no coupling was performed for the upper part of the basin. For these uncoupled areas, PCR-GLOBWB is run in stand-alone mode, and water is routed towards the coupled domain using the kinematic wave approximation. Within the coupled area, the LDD of PCR-GLOBWB was deactivated to prevent further routing in the hydrologic model. As a last step in the coupling algorithm, FM was updated and integrated forward in time until it reached the same model time step as PCR-GLOBWB to compute daily inundation and discharge values. Since only a one-way coupling approach is tested, water added to FM can only be routed downstream, 
but cannot infiltrate or evaporate, most likely leading to overestimation of modelled discharge and inundation.

\section{Results and discussion}

\subsection{Discharge simulation at Óbidos}

PCR-GLOBWB-DynRout reproduces low flows well, but fails in reproducing the observed variation in discharge as shown by a low coefficient of determination (Table 1). This low value can be attributed to the rugged hydrograph obtained, as shown in Fig. 5. The strong fluctuations cannot be fully explained, but we assume that they may be related to the simplistic routing scheme used, as discharge results for the coupled run do not show such behaviour, although they receive the same hydrologic input. In addition, peak discharge is generally modelled too early. This low performance is related to PCR-GLOBWB-DynRout being a global hydrologic model, thus not specifically designed for simulating discharge at the basin scale despite the regional optimization technique applied for this study. The employed kinematic wave approximation as well as the coarse resolution of $30 \mathrm{arcmin}$ can be identified as factors currently hampering a more accurate simulation of discharge.

Forcing the model with discharge observed at GRDC stations, we found that the aggregated input discharge as obtained from upstream GRDC station observations (Fig. 1) accounted for only $59 \%$ of the discharge generated in the basin as observed at Óbidos (Fig. 6). This underrepresentation can be linked to the discrepancy between catchment area at Óbidos and summed catchment area of all input stations upstream of Óbidos. Comparing both, we found that only $63 \%$ of upstream catchment area at Óbidos is accounted for by input stations (Table 2). The differences in discharge can therefore be attributed to the additional discharge created in the intermediate area between Óbidos and the upstream inflow stations. To avoid the expectable discharge estimates that are too low and facilitate comparability with other model runs, we therefore decided to scale the input discharge values accordingly. The results then reveal that the strength of purely hydrodynamic runs is the correct reproduction of discharge variability, as shown by high coefficients of determination. Still, model results obtained with only Delft 3D FM resulted in lagged discharge, with the 1-D/2-D schematization having lower discharge results and a larger time lag. We suspect that the obtained attenuation and time lag for both 2$\mathrm{D}$ and 1-D/2-D schematization result from the absence of any internal forcing. By using only upstream discharge boundaries and neglecting internal sources, discharge will need longer to propagate until Óbidos due to the larger average travel distance. It should be noted that, from a computational point of view, the 1-D/2-D set-up has the advantage of a $25 \%$ lower wall clock time required to finish the simulation period compared to the 2-D set-up.
Table 1. Performance of model runs in objective functions for both actual and scaled model input. The term "1way" indicates one-way coupled runs.

\begin{tabular}{lrrrrr}
\hline & DynRout & $2-\mathrm{D}$ & 1-D/2-D & $2-\mathrm{D}$ & 1-D/2-D \\
& & GRDC & GRDC & 1way & 1way \\
\hline$r^{2}$ & 0.49 & 0.92 & 0.85 & 0.77 & 0.83 \\
RMSE & 34100 & 16229 & 18735 & 21451 & 19548 \\
KGE & 0.64 & 0.80 & 0.86 & 0.84 & 0.79 \\
\hline
\end{tabular}

Assessing model results for the coupled runs, we see that the simulated discharge is higher than that of both the purely hydrology-based and purely hydrodynamic-based models. Deviations between coupled and GRDC runs can be ascribed to differences in forcing, which are not only different in terms of input volumes but also in terms of input locations. We also find that the coupled runs do not reach the same variability in discharge as the GRDC-forced runs, although they are employing the same model schematizations. This may be related to a higher proportion of overland flow resulting from distributing water volumes over the FM cells, which would reduce discharge dynamics. The disparities in discharge of coupled runs compared to PCR-GLOBWB-DynRout, however, have to be attributed to a combination of differences between model schematizations and process representation as we have carefully examined the water balance throughout the entire coupling process, and therefore can exclude volume errors as sources of deviations. First, Delft 3D FM and PCR-GLOBWB-DynRout differ in their spatial resolution, with the latter having a much coarser spatial resolution. Eventually, this difference can have an impact on modelled discharge accuracy, because the role of channel-floodplain interaction is pivotal for inundation and discharge estimates and so is schematization of connecting channels (Neal et al., 2012; Rudorff et al., 2014a; Savage et al., 2016) which both are facilitated by using finer spatial resolution. This is underlined by the smoothed daily discharge which results when replacing the simple kinematic wave routing at 30 arcmin spatial resolution with a hydrodynamic model at fine spatial resolution, even though both are subject to the same meteorological forcing as well as hydrologic processes. Second, differences in process description can lead to improved discharge estimates compared to PCR-GLOBWB-DynRout. In particular, solving the SWE - as implemented in Delft 3D FM - instead of the kinematic wave approximation may have influenced results, as it accounts for back-water effects which play an important role in the Amazon Basin because of its low gradients (Meade et al., 1991; Moussa and Bocquillon, 1996; Paiva et al., 2013). Third, our coupled set-ups may yield higher discharge than PCR-GLOBWB-DynRout due to the one-directional coupling scheme implemented. For peak flow conditions, the higher discharge can be attributed to the absence of important groundwater infiltration and evapora- 


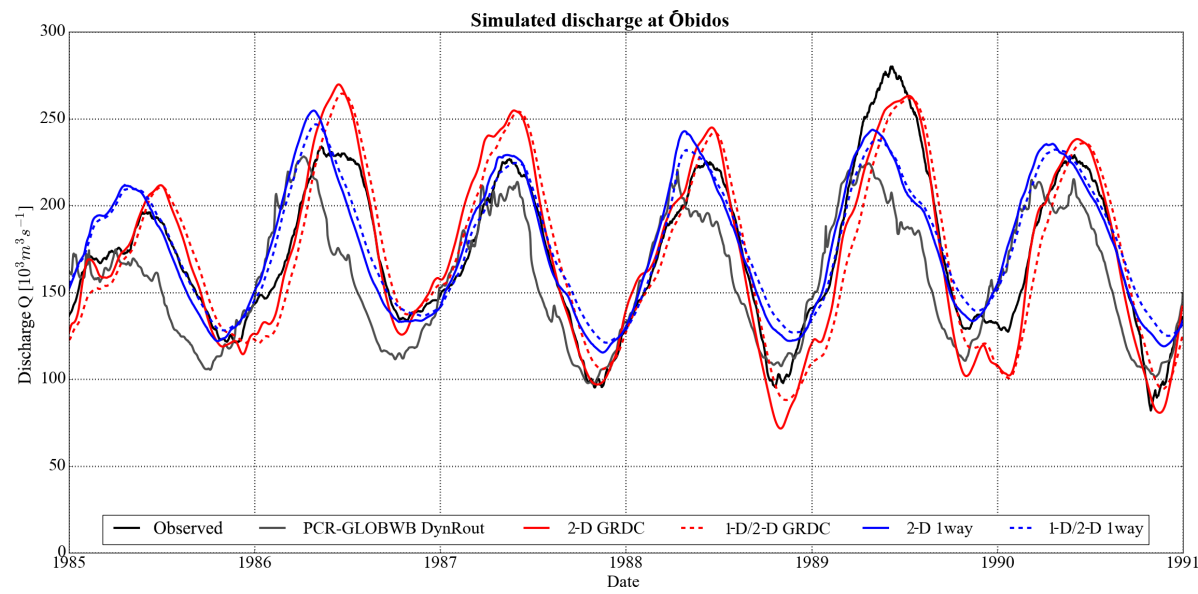

Figure 5. Plot of all model results and observed discharge values at GRDC station Óbidos.

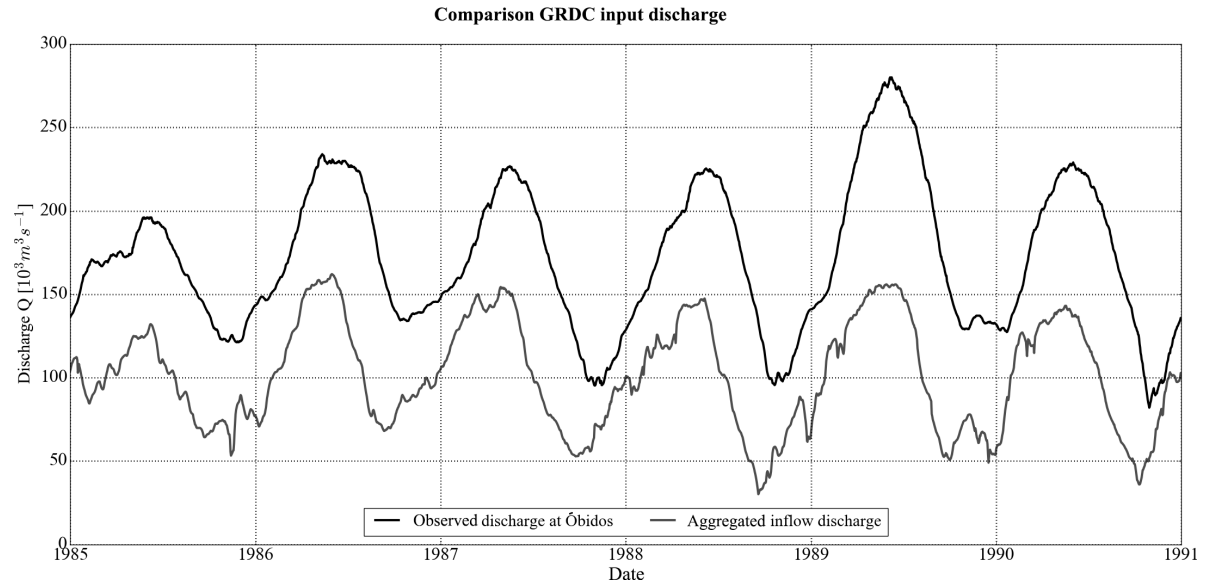

Figure 6. Comparison of input discharge aggregated over all GRDC stations upstream of Óbidos and the observed discharge.

tion processes on inundated areas, resulting in increased surface water volumes routed downstream. Note that in PCRGLOBWB-DynRout flooded areas are subject to evaporation which can partly explain the higher discharge resulting from the one-directionally coupled model. During low flow conditions, however, the excess water that remained on the floodplains, although it should have infiltrated or evaporated, can return into the channel, resulting in higher discharge too. Comparing our results to other studies, we find that both coupled runs have remarkably lower RMSE than those reported in Alfieri et al. (2013) for GloFAS. The obtained coefficients of determination come close to those by Yamazaki et al. (2011, 2012b), who connected runoff from a land surface model with a river-floodplain routing scheme.

\subsection{Water level and extent of inundation}

Assessing modelled inundation water levels, we find that, because discharge results are almost identical, simulated water levels for the GRDC-fed runs differ only slightly be- tween 2-D and 1-D/2-D schematization, with the latter generally showing lower water levels (Fig. 7). This is the result of the 1-D channels providing better hydraulic connectivity throughout the study area since also smaller side channels below the spatial resolution of the 2-D mesh are accounted for (Fig. 8). Results furthermore show that for some observation locations, the GRDC runs yield higher water level values than one-way coupled runs and vice versa at other locations. As the model schematizations are exactly the same, these local differences can be related to the difference in volume input into the FM model domain (dividing over FM cells with PCR-GLOBWB output versus upstream boundaries with GRDC data), as well as local influence of precipitation events within the intermediate catchment area on water level dynamics. The discrepancy between simulated water level for 1-D/2-D and 2-D set-ups at Loc2 exemplifies the impact vertical errors in input elevation data can have on 2-D schematizations. While the area where the location was placed could be conveyed by the 1-D network, this was not possible in the 2-D set-up, thus resulting in local accumu- 

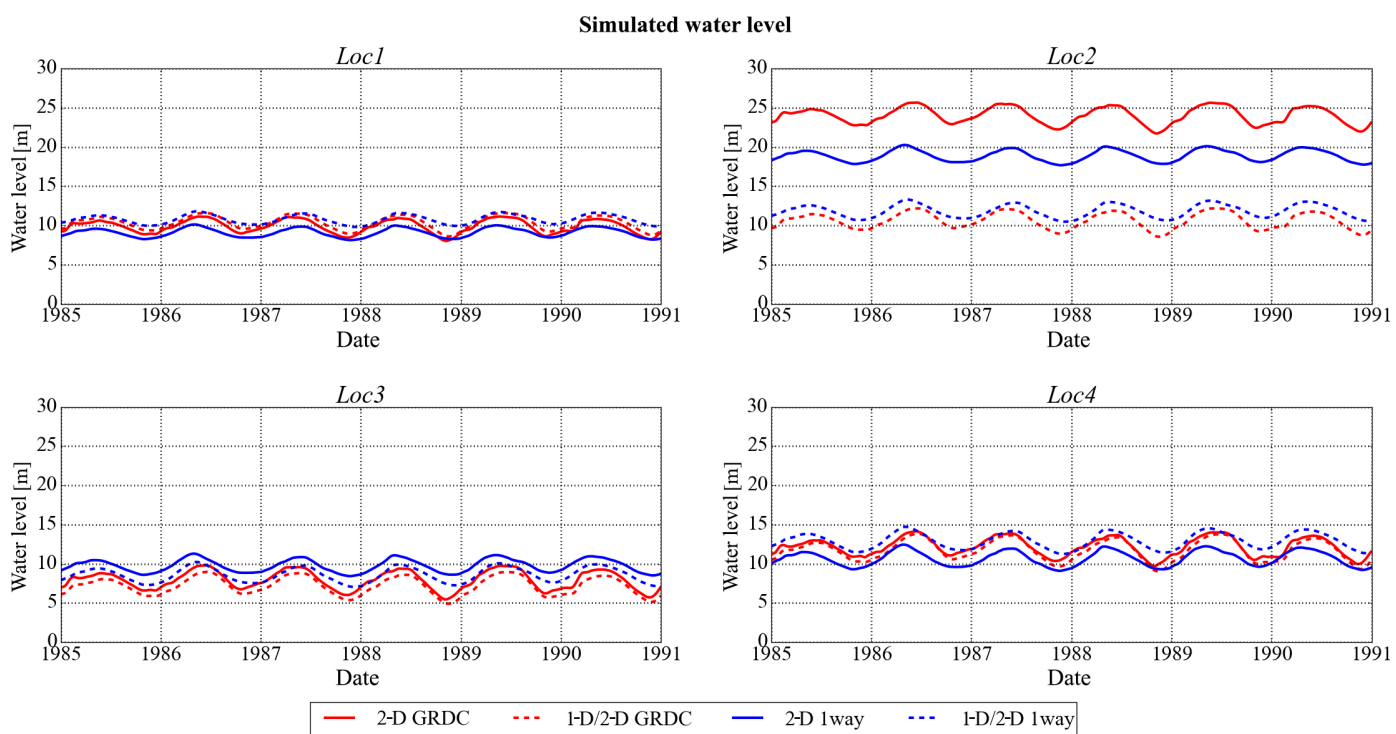

Figure 7. Plot of simulated water levels at four different observation locations throughout the study domain.
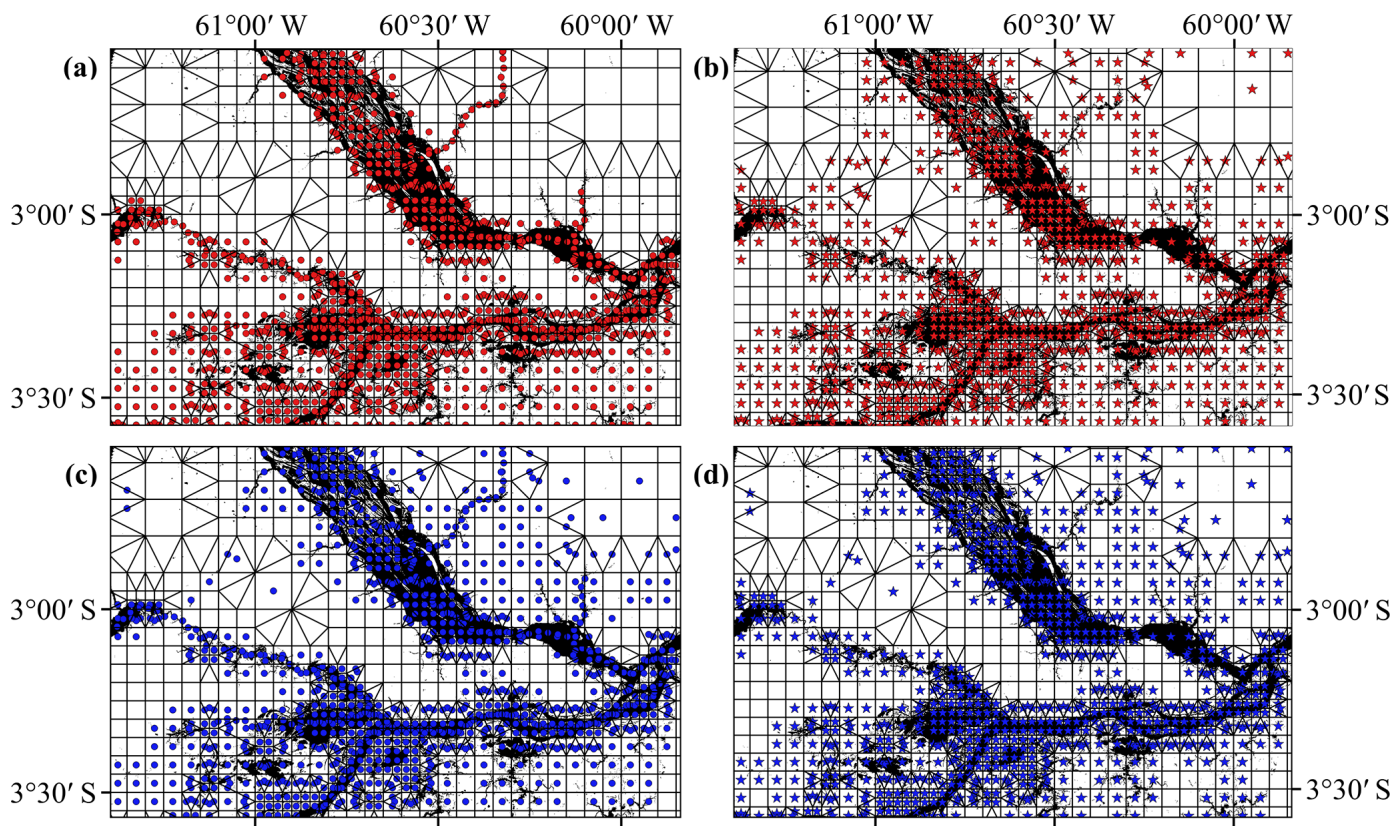

(d)

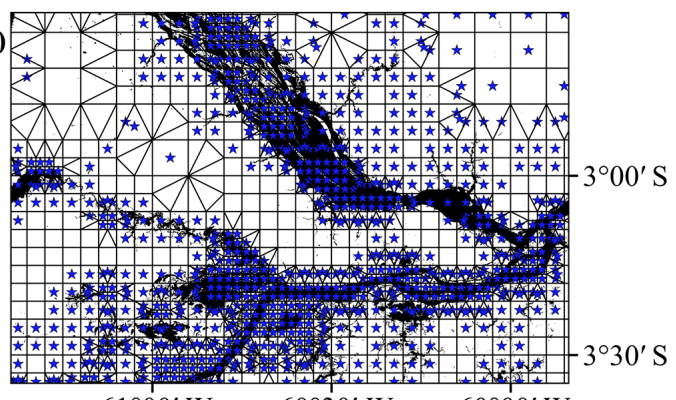

$61^{\circ} 00^{\prime} \mathrm{W}$

$60^{\circ} 30^{\prime} \mathrm{W}$

$60^{\circ} 00^{\prime} \mathrm{W}$

$61^{\circ} 00^{\prime} \mathrm{W}$

$60^{\circ} 30^{\prime} \mathrm{W}$

$60^{\circ} 00^{\prime} \mathrm{W}$

Legend

- FM grid • 1-D/2-D GRDC * 2-D GRDC • 1-D/2-D 1way * 2-D 1way

Figure 8. Plot of simulated inundation extent per model set-up compared to observed water body extent as observed by LandSat imagery on 1 July 1989; the validation is performed for (a) the 1-D/2-D GRDC run, (b) the 2-D GRDC run, (c) the 1-D/2-D one-way (1way) run, and (d) the 2-D one-way (1way) run.

lation of water in a local depression. Results also indicate that locations closer to the delta (see Loc4 as an example) are less influenced by river dynamics or precipitation events, but more by the downstream water level boundary, for which smaller differences in simulated water level between model runs are revealed. From a holistic point of view, large-scale water level dynamics are correctly represented with only minor differences between model set-ups, despite the results at Loc2 as mentioned above.

In terms of inundation extent, we performed a first-order and only qualifying validation of simulated against observed water extent for all runs except the DynRout set-up. Our re- 


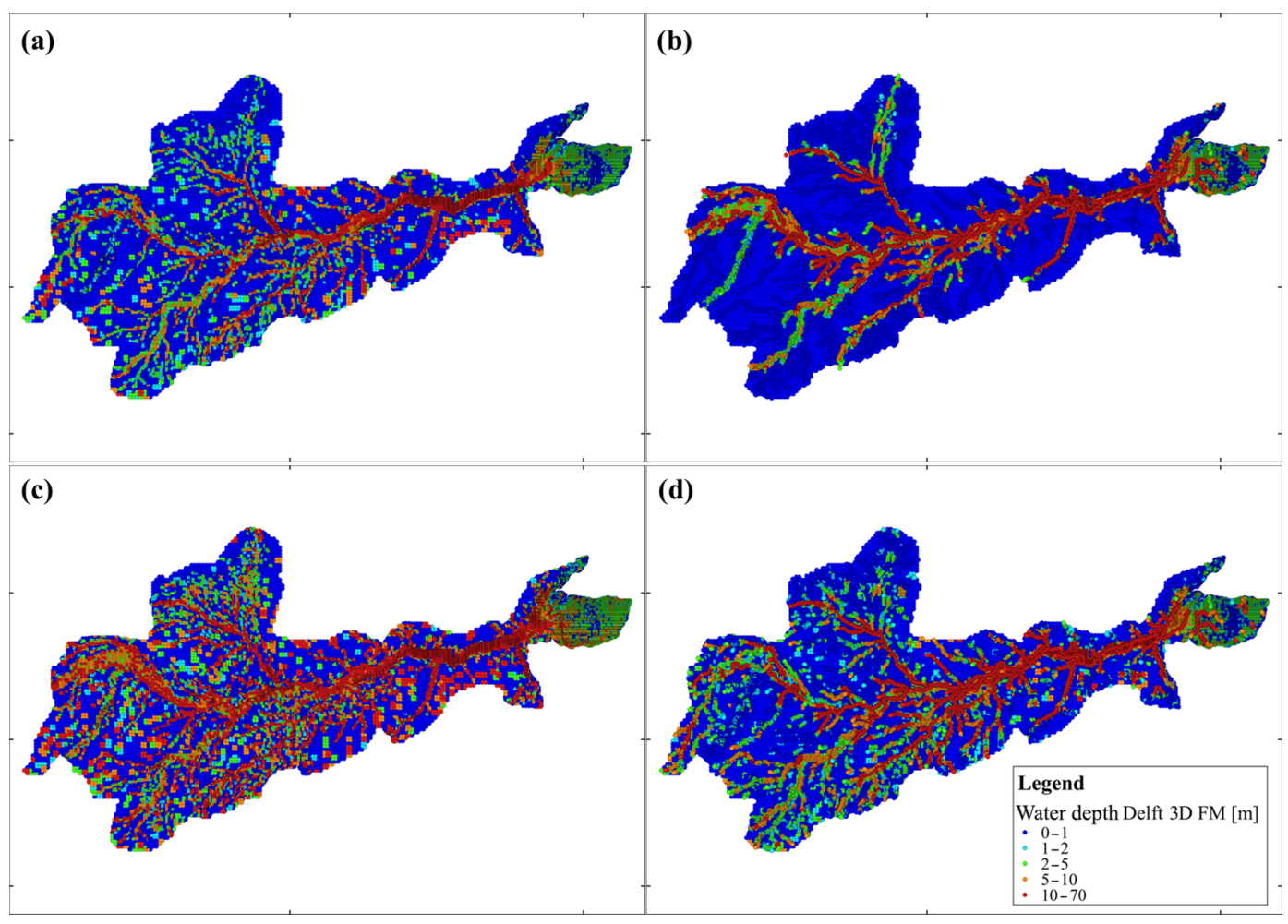

Figure 9. Plots of simulated water depth for 31 October 1990 for all runs with Delft 3D FM: (a) 2-D GRDC run; (b) 1-D/2-D GRDC run; (c) 2-D one-way (1way) run; and (d) 1-D/2-D one-way (1way) run.

Table 2. List with catchment area per GRDC station located upstream of Óbidos (type "i”) compared to catchment area of observation station Óbidos (type "o"). All data are sourced from the official GRDC website (http://www.grdc.sr.unh.edu).

\begin{tabular}{|c|c|c|c|}
\hline Type & GRDC station name & $\begin{array}{l}\text { GRDC } \\
\text { station } \\
\text { number }\end{array}$ & $\begin{array}{r}\text { GRDC } \\
\text { catchment } \\
\text { area }\left(\mathrm{km}^{2}\right)\end{array}$ \\
\hline $\mathrm{i}$ & Caracaraí & 3618500 & 124980 \\
\hline $\mathrm{i}$ & Uaracu & 3618950 & 40506 \\
\hline $\mathrm{i}$ & Acanaui & 3621200 & 242259 \\
\hline $\mathrm{i}$ & São Paulo de Olivença & 3623100 & 990781 \\
\hline $\mathrm{i}$ & Gavião & 3624120 & 162000 \\
\hline $\mathrm{i}$ & Arumã-Jusante & 3625310 & 359853 \\
\hline $\mathrm{i}$ & Porto Velho & 3627040 & 954285 \\
\hline $\mathrm{i}$ & Ji-Paraná (Rondônia) & 3627408 & 32606 \\
\hline $\mathrm{i}$ & Estirao Da Angelica & 3628500 & 26040 \\
\hline \multicolumn{3}{|c|}{$\sum$ (catchment area input stations) } & 2933310 \\
\hline o & Óbidos & 3629000 & 4640300 \\
\hline \multicolumn{3}{|c|}{ Proportional representation of catchment area } & $63 \%$ \\
\hline
\end{tabular}

sults indicate that the 1-D-2-D schematization with GRDC forcing performs particularly well (see Fig. 8). This demonstrates that the advantage of implementing 1-D channels as inundation extent is modelled more accurately, especially for smaller side branches of the stream where the 2-D resolution does not allow for detailed simulation of channel-floodplain interaction. This finding is in line with the observations made by Neal et al. (2012), who employed a sub-gridding scheme. For the coupled set-ups, water extent is well modelled for the main reaches of the river, but overpredicted for floodplain areas. We attribute these deviations to both the quality of remotely sensed input elevation and the coarse spatial resolution of the flexible mesh which may overly facilitate flow over floodplains. Besides, distributing water volumes over the FM cells in the coupling process may also have led to stronger inundation on floodplain areas than point inflow from GRDC stations. Assessing simulated water extent over the entire study area, we again find that the use of 1-D channels can highly improve the level of detail for river streams and bends for both the main branch as well as more remote areas, as shown in Fig. 9. Similar to the local water level validation, we found that the areas where inundation is modelled differ strongly compared to the GRDC runs. While inundation for those runs is limited to streams that are connected to upstream discharge boundaries, spatially coupling hydrology with hydrodynamics additionally yields inundation information for smaller reaches throughout the entire model domain which otherwise would not be fed with water. In particular, for the 1-D/2-D run, this results in an overall good representation of inundation along rivers throughout the entire model domain. This constitutes a major improvement, 
and is a strong hint that model coupling can indeed contribute to better inundation extent estimates. Notwithstanding this achievement, we again see that water can accumulate locally, which can partially be related to the presence of temporarily filled depressions during rainfall, and partially to the spatial resolution of the hydrodynamic model in combination with the quality of the elevation data used for model schematization. Also, in the big picture, the local accumulation of water is less severe in the 1-D/2-D than in the 2-D set-up due to a facilitated hydrologic connectivity within the river basin.

\section{Conclusion and recommendations}

In the present study, we spatially coupled the global hydrologic model PCR-GLOBWB with the state-of-the-art hydrodynamic model Delft 3D FM, and compared resulting discharge and inundation extent with estimates obtained from stand-alone runs as well as actual observations to investigate possible strengths, weaknesses, and opportunities of model coupling for large-scale inundation modelling.

Our results showed that hydrology-only runs conducted with PCR-GLOBWB-DynRout have the least accurate discharge simulation of all runs. Particularly discharge variability could not be captured by a global hydrology model due to its coarse spatial resolution and its kinematic wave approximation of surface water flow in an area with limited topographic gradients. The question therefore remains: which is the most important, the coarse resolution or the simple hydrodynamics? Therefore, once PCR-GLOBWB at 5 arcmin spatial resolution is fully tested and available, the model runs should be repeated to better understand whether results can be improved by finer spatial resolution or are constrained by the employment of a kinematic wave approach. Besides, finetuning of sensitive parameters of PCR-GLOBWB at a global scale seems to be required to obtain a better-timed peak flow, not only for those optimized so far but also others such as Manning's surface roughness coefficient.

Comparison revealed that runs forced with observed discharge from GRDC, once the underrepresentation of water volume in the systems was accounted for, outperform hydrology-based models in resembling discharge dynamics. While validation of GRDC-forced runs against observed discharge showed good performance, the disadvantage of such set-ups is the limitation of discharge to river reaches fed by the discharge boundaries. As a result, inundations along reaches that start within in the domain or along reaches not being fed by upstream discharge boundaries cannot be simulated. A first qualitative validation of simulated inundation extent with Landsat imagery showed that, for those rivers connected to upstream discharge boundaries, the 1-D-2-D schematization with GRDC forcing showed the best performance of all runs. Representation of 1-D channels results in a better conveyance of surface water in the model domain and consequently less flood artefacts, in particular where 1-
D channel dimension is below the grid size of the 2-D grid cells. We also found that GRDC-forced runs show stronger attenuation and lagged peak discharge due to the longer average travel time required to propagate from the boundaries through the model domain.

Both 1-D/2-D and 2-D coupled runs were able to capture the peak flow better than GRDC runs, and to follow the discharge dynamics better than the simple kinematic wave model. The fact that they overpredict peak discharge for some years can be attributed to the absence of a feedback loop to hydrological processes on floodplains, such as groundwater infiltration and evaporation. It will be the aim of a follow-up study to implement a fully dynamic coupling scheme, whereby information is exchanged between hydrology and hydrodynamics at each time step, and water on the floodplains is allowed to evaporate or recharge the groundwater store. We expect that this will lead to lower and more accurate discharge estimates. Replacing the simplistic routing scheme of PCR-GLOBWB with a full hydrodynamic model remarkably improves the coefficient of determination as well as the model's skill. From our results we conclude that spatially coupling hydrology and hydrodynamics merges the best of two worlds, namely water volume accuracy and routing scheme. From a computational point of view, the use of a 1-D/2-D set-up is favourable, as it requires less computational time. At the same time, it yields a better spatial resolution of the river network than the 2-D set-up because it decreases dependency on quality of space-borne DEM data sets which are known for introducing errors in large-scale inundation models. Especially for the coupled runs, these vertical errors are partly responsible for overestimated inundation extent and local water levels, in particular in floodplain regions. Another part of the overestimation may lie in the way water volumes are distributed over the 2-D grid. It needs to be researched in more detail how the distribution of volumes impacts model results, and whether other techniques such as adding water directly into the 1-D channels than onto the 2D grid may improve model performance. Besides, a future study should contain an assessment of the impact of varying spatial resolution of both the hydrologic and the hydrodynamic model as well as their interplay to obtain a better picture of the potential of model coupling at larger scales.

In this study, we used only global data sets for both the hydrological and the newly developed hydrodynamic model Delft 3D FM. Thus, the presented set-up can easily be applied in other river basins as well. In the long term, we are confident that the proposed spatially coupled model set-up can eventually contribute to a better assessment of both current and future flood hazard and risk.

Author contributions. Arjen V. Haag prepared the code for model coupling. Arthur van Dam supported the application of Delft 3D Flexible Mesh and Ludovicus P. H. van Beek provided information for PCR-GLOBWB and PCR-GLOBWB-DynRout runs. Ludovicus P. H. van Beek, Hessel C. Winsemius, and Marc F. P. Bierkens 
supervised the research and provided important advice. Jannis M. Hoch designed and executed the research, and also prepared the manuscript, with contribution from all co-authors.

Acknowledgements. The authors declare that they have no conflict of interest. The authors want to acknowledge the valuable contributions of Gennadii Donchyts, Herman Kernkamp and Robert Leander from Deltares as well as Edwin Sutanudjaja from Utrecht University. This study was financed by the EIT ClimateKIC programme under project title "Global high-resolution database of current and future river flood hazard to support planning, adaption and re-insurance". We want to acknowledge the constructive contributions of one anonymous reviewer and Dai Yamazaki who helped to strongly increase the quality of the manuscript.

Edited by: N. Verhoest

Reviewed by: D. Yamazaki and one anonymous referee

\section{References}

Alfieri, L., Burek, P., Dutra, E., Krzeminski, B., Muraro, D., Thielen, J., and Pappenberger, F.: GloFAS-global ensemble streamflow forecasting and flood early warning, Hydrol. Earth Syst. Sci., 17, 1161-1175, doi:10.5194/hess-17-1161-2013, 2013.

Alfieri, L., Salamon, P., Bianchi, A., Neal, J. C., Bates, P., and Feyen, L.: Advances in pan-European flood hazard mapping, Hydrol. Process., 28, 4067-4077, doi:10.1002/hyp.9947, 2014.

Andreadis, K. M., Schumann, G. J.-P., and Pavelsky, T. M.: A simple global river bankfull width and depth database, Water Resour. Res., 49, 7164-7168, doi:10.1002/wrcr.20440, 2013.

Bates, P. D. and de Roo, A.: A simple raster-based model for flood inundation simulation, J. Hydrol., 236, 54-77, doi:10.1016/S0022-1694(00)00278-X, 2000.

Baugh, C. A., Bates, P. D., Schumann, G. J.-P., and Trigg, M. A.: SRTM vegetation removal and hydrodynamic modeling accuracy, Water Resour. Res., 49, 5276-5289, doi:10.1002/wrcr.20412, 2013.

Berry, P. A. M., Garlick, J. D., and Smith, R. G.: Near-global validation of the SRTM DEM using satellite radar altimetry, Remote Sens. Environ., 106, 17-27, doi:10.1016/j.rse.2006.07.011, 2007.

Biancamaria, S., Bates, P. D., Boone, A., and Mognard, N. M.: Large-scale coupled hydrologic and hydraulic modelling of the $\mathrm{Ob}$ river in Siberia, J. Hydrol., 379, 136-150, doi:10.1016/j.jhydrol.2009.09.054, 2009.

Bierkens, M. F. P.: Global hydrology 2015: State, trends, and directions, Water Resour. Res., 51, 4923-4947, doi:10.1002/2015WR017173, 2015.

Bierkens, M. F. P., Bell, V. A., Burek, P., Chaney, N., Condon, L. E., David, C. H., de Roo, A., D??11, P., Drost, N., Famiglietti, J. S., Flörke, M., Gochis, D. J., Houser, P., Hut, R., Keune, J., Kollet, S., Maxwell, R. M., Reager, J. T., Samaniego, L., Sudicky, E., Sutanudjaja, E. H., van de Giesen, N., Winsemius, H. C., and Wood, E. F.: Hyper-resolution global hydrological modelling: What is next?: "Everywhere and locally relevant," Hydrol. Process., 29, 310-320, doi:10.1002/hyp.10391, 2015.
Butts, M., Drews, M., Larsen, M. A. D., Lerer, S., Rasmussen, S. H., Grooss, J., Overgaard, J., Refsgaard, J. C., Christensen, O. B., and Christensen, J. H.: Embedding complex hydrology in the regional climate system - Dynamic coupling across different modelling domains, Adv. Water Resour., 74, 166-184, doi:10.1016/j.advwatres.2014.09.004, 2014.

Carabajal, C. C. and Harding, D. J.: SRTM C-band and ICESat laser altimetry elevation comparisons as a function of tree cover and relief, Photogramm. Eng. Remote Sens., 73, 287-298, doi:10.14358/PERS.72.3.287, 2006.

Castro Gama, M., Popescu, I., Mynett, A., Shengyang, L., and van Dam, A.: Modelling extreme flood hazard events on the middle Yellow River using DFLOW-flexible mesh approach, Nat. Hazards Earth Syst. Sci. Discuss., 1, 6061-6092, doi:10.5194/nhessd-1-6061-2013, 2013.

Ceola, S., Laio, F., and Montanari, A.: Satellite nighttime lights reveal increasing human exposure to floods worldwide, Geophys. Res. Lett., 41, 7184-7190, doi:10.1002/2014GL061859, 2014.

Chen, C., Liu, H., and Beardsley, R. C.: An Unstructured Grid, Finite-Volume, Three-Dimensional, Primitive Equations Ocean Model: Application to Coastal Ocean and Estuaries, J. Atmos. Ocean. Tech., 20, 159-186, doi:10.1175/15200426(2003)020<0159:AUGFVT>2.0.CO;2, 2003.

CSDMS: CSDMS Basic Model Interface (version 1.0), available at: https://csdms.colorado.edu/wiki/BMI_Description, last access: 25 August 2016.

de Graaf, I. E. M., Sutanudjaja, E., van Beek, L. P. H., and Bierkens, M. F. P.: A high-resolution global-scale groundwater model, Hydrol. Earth Syst. Sci., 19, 823-837, doi:10.5194/hess-19-8232015, 2015.

Deltares: D-Flow Flexible Mesh Technical Reference Manual (Draft), available at: http://content.oss.deltares.nl/delft3d/ manuals/D-Flow_FM_Technical_Reference.pdf (last access: 21 October 2015), 2016.

Döll, P., Kaspar, F., and Lehner, B.: A global hydrological model for deriving water availability indicators: model tuning and validation, J. Hydrol., 270, 105-134, doi:10.1016/S00221694(02)00283-4, 2003.

Dottori, F., Salamon, P., Bianchi, A., Alfieri, L., Hirpa, F., and Feyen, L.: Development and evaluation of a framework for global flood hazard mapping, Adv. Water Resour., 94, 87-102, doi:10.1016/j.advwatres.2016.05.002, 2016.

Finaud-Guyot, P., Delenne, C., Guinot, V., and Llovel, C.: 1D-2D coupling for river flow modeling, Comptes Rendus Mécanique, 339, 226-234, doi:10.1016/j.crme.2011.02.001, 2011.

Getirana, A. C. V, Bonnet, M., and Martinez, J.: Evaluating parameter effects in a DEM “ burning " process based on land cover data, Hydrol. Process., 23, 2316-2325, doi::10.1002/hyp.7303, 2009.

Gupta, H. V, Kling, H., Yilmaz, K. K., and Martinez, G. F.: Decomposition of the mean squared error and NSE performance criteria?: Implications for improving hydrological modelling, J. Hydrol., 377, 80-91, doi:10.1016/j.jhydrol.2009.08.003, 2009.

Hagen, E. and Lu, X. X.: Let us create flood hazard maps for developing countries, Nat. Hazards, 58, 841-843, doi:10.1007/s11069-011-9750-7, 2011.

Harris, I., Jones, P. D., Osborn, T. J., and Lister, D. H.: Updated high-resolution grids of monthly climatic observations 
- the CRU TS3.10 Dataset, Int. J. Climatol., 34, 623-642, doi:10.1002/joc.3711, 2014.

Hirabayashi, Y., Mahendran, R., Koirala, S., Konoshima, L., Yamazaki, D., Watanabe, S., Kim, H., and Kanae, S.: Global flood risk under climate change, Nat. Publ. Gr., 3, 816-821, doi:10.1038/nclimate1911, 2013.

Huang, C., Chen, Y., and Wu, J.: Mapping spatio-temporal flood inundation dynamics at large river basin scale using time-series flow data and MODIS imagery, Int. J. Appl. Earth Obs. Geoinf., 26, 350-362, doi:10.1016/j.jag.2013.09.002, 2014.

Jongman, B., Ward, P. J., and Aerts, J. C. J. H.: Global exposure to river and coastal flooding: Long term trends and changes, Global Environ. Change, 22, 823-835, doi:10.1016/j.gloenvcha.2012.07.004, 2012.

Jongman, B., Hochrainer-Stigler, S., Feyen, L., Aerts, J. C. J. H., Mechler, R., Botzen, W. J. W., Bouwer, L. M., Pflug, G., Rojas, R., and Ward, P. J.: Increasing stress on disasterrisk finance due to large floods, Nat. Clim. Change, 4, 1-5, doi:10.1038/NCLIMATE2124, 2014.

Kållberg, P., Berrisford, P., Hoskins, B., Simmons, A., Uppala, S., Lamy-Thepaut, S., and Hine, R.: ERA-40 atlas, ERA-40 Proj. Rep. Ser. 19, Eur. Cent. for Medium Range Weather Forecasts, Reading, UK, 2005.

Karssenberg, D., Schmitz, O., Salamon, P., de Jong, K., and Bierkens, M. F. P.: A software framework for construction of process-based stochastic spatio-temporal models and data assimilation, Environ. Model. Softw., 25, 489-502, doi:10.1016/j.envsoft.2009.10.004, 2010.

Kernkamp, H. W. J., van Dam, A., Stelling, G. S., and de Goede, E. D.: Efficient scheme for the shallow water equations on unstructured grids with application to the Continental Shelf, Ocean Dynam., 61, 1175-1188, doi:10.1007/s10236-011-0423-6, 2011.

Kinzel, P. J., Legleiter, C. J., and Nelson, J. M.: Mapping River Bathymetry With a Small Footprint Green LiDAR: Applications and Challenges, J. Am. Water Resour. Assoc., 49, 183-204, doi:10.1111/jawr.12008, 2013.

Kling, H., Stanzel, P., Fuchs, M., and Nachtnebel, H.-P.: Performance of the COSERO precipitation-runoff model under nonstationary conditions in basins with different climates, Hydrolog. Sci. J., 60, 1374-1393, doi:10.1080/02626667.2014.959956, 2015.

Legleiter, C. J.: Calibrating remotely sensed river bathymetry in the absence of field measurements: Flow REsistance EquationBased Imaging of River Depths (FREEBIRD), Water Resour. Res., 51, 2865-2884, doi:10.1002/2014WR016624, 2015.

Legleiter, C. J.: Inferring river bathymetry via Image-to-Depth Quantile Transformation (IDQT), Water Resour. Res., 52, 37223741, doi:10.1002/2016WR018730, 2016.

Lehner, B., Verdin, K., and Jarvis, A.: New Global Hydrography Derived From Spaceborne Elevation Data, Eos T. Am. Geophys. Un., 8, 93-94, doi:10.1029/2008EO100001, 2008.

Leopold, L. B. and Maddock, T. J.: The hydraulic geometry of stream channels and some physiographic implications, US Geol. Surv. Prof. Pap. 252, US Geological Survey, 56 pp., 1953.

Li, H., Beldring, S., and Xu, C.-Y.: Stability of model performance and parameter values on two catchments facing changes in climatic conditions, Hydrolog. Sci. J., 60, 1317-1330, doi:10.1080/02626667.2014.978333, 2015.
Liang, X., Lettenmaier, D. P., Wood, E. F., and Burges, S. J.: A simple hydrologically based model of land surface water and energy fluxes for general circulation models, J. Geophys. Res.-Atmos., 99, 14415-14428, doi:10.1029/94JD00483, 1994.

Lima, I. B. T., Rosa, R. R., Ramos, F. M., and de Moraes Novo, E. M. L.: Water level dynamics in the Amazon floodplain, Adv. Water Resour., 26, 725-732, doi:10.1016/S0309-1708(03)00052-6, 2003.

Liu, Q., Qin, Y., Zhang, Y., and Li, Z.: A coupled 1D-2D hydrodynamic model for flood simulation in flood detention basin, Nat. Hazards, 75, 1303-1325, doi:10.1007/s11069-014-1373-3, 2015.

Meade, R. H., Rayol, J. M., Da Conceição, S. C., and Natividade, J. R. G.: Backwater Effects in the Amazon River of Basin, Environ. Geol. Water Sci., 18, 105-114, doi:10.1007/BF01704664, 1991.

Molinier, M., Ronchail, J., Guyot, J. L., Cochonneau, G., Guimarães, V., and de Olveira, E.: Hydrological variability in the Amazon drainage basin and African tropical rivers, Hydrol. Process., 23, 3245-3252, doi:10.1002/hyp.7400, 2009.

Moussa, R. and Bocquillon, C.: Criteria for the choice of floodrouting methods in natural channels, J. Hydrol., 186, 1-30, doi:10.1016/S0022-1694(96)03045-4, 1996.

Muis, S., Verlaan, M., Winsemius, H. C., Aerts, J. C. J. H., and Ward, P. J.: A global reanalysis of storm surges and extreme sea levels, Nat. Commun., 7, 11969, doi:10.1038/ncomms11969, 2016.

Munich Re: Topics Geo, natural catastrophes 2009: analyses, assessments, positions, Munich Reinsurance Group, Munich, Germany, 2010.

Naz, B. S., Frans, C. D., Clarke, G. K. C., Burns, P., and Lettenmaier, D. P.: Modeling the effect of glacier recession on streamflow response using a coupled glacio-hydrological model, Hydrol. Earth Syst. Sci., 18, 787-802, doi:10.5194/hess-18-7872014, 2014.

Neal, J. C., Schumann, G. J.-P., and Bates, P. D.: A subgrid channel model for simulating river hydraulics and floodplain inundation over large and data sparse areas, Water Resour. Res., 48, 1-16, doi:10.1029/2012WR012514, 2012.

Paiva, R. C. D., Collischonn, W., and Tucci, C. E. M.: Large scale hydrologic and hydrodynamic modeling using limited data and a GIS based approach, J. Hydrol., 406, 170-181, doi:10.1016/j.jhydrol.2011.06.007, 2011.

Paiva, R. C. D., Collischonn, W., and Buarque, D. C.: Validation of a full hydrodynamic model for large-scale hydrologic modelling in the Amazon, Hydrol. Process., 27, 333-346, doi:10.1002/hyp.8425, 2013.

Pappenberger, F., Matgen, P., Beven, K. J., Henry, J. B., Pfister, L., and Fraipont, P.: Influence of uncertain boundary conditions and model structure on flood inundation predictions, Adv. Water Resour., 29, 1430-1449, doi:10.1016/j.advwatres.2005.11.012, 2006.

Pappenberger, F., Dutra, E., Wetterhall, F., and Cloke, H. L.: Deriving global flood hazard maps of fluvial floods through a physical model cascade, Hydrol. Earth Syst. Sci., 16, 4143-4156, doi:10.5194/hess-16-4143-2012, 2012.

Peckham, S. D., Hutton, E. W. H., and Norris, B.: A component-based approach to integrated modeling in the geosciences: The design of CSDMS, Comput. Geosci., 53, 3-12, doi:10.1016/j.cageo.2012.04.002, 2013. 
Rennó, C. D., Nobre, A. D., Cuartas, L. A., Soares, J. V., Hodnett, M. G., Tomasella, J., and Waterloo, M. J.: HAND, a new terrain descriptor using SRTM-DEM: Mapping terra-firme rainforest environments in Amazonia, Remote Sens. Environ., 112, 3469-3481, doi:10.1016/j.rse.2008.03.018, 2008.

Rudorff, C. M., Melack, J. M., and Bates, P. D.: Flooding dynamics on the lower Amazon floodplain: 1. Hydraulic controls on water elevation, inundation extent, and river-floodplain discharge, Water Resour. Res., 50, 619-634, doi:10.1002/2013WR014091, 2014a.

Rudorff, C. M., Melack, J. M., and Bates, P. D.: Flooding dynamics on the lower Amazon floodplain: 2. Seasonal and interannual hydrological variability, Water Resour. Res., 50, 635-649, doi:10.1002/2013WR014714, 2014b.

Sampson, C. C., Smith, A. M., Bates, P. D., Neal, J. C., Alfieri, L., and Freer, J. E.: A high-resolution global flood hazard model, Water Resour. Res., 51, 7358-7381, doi:10.1002/2015WR016954, 2015.

Sanders, B. F.: Evaluation of on-line DEMs for flood inundation modeling, Adv. Water Resour., 30, 1831-1843, doi:10.1016/j.advwatres.2007.02.005, 2007.

Savage, J. T. S., Bates, P. D., Freer, J., Neal, J. C., and Aronica, G.: When does spatial resolution become spurious in probabilistic flood inundation predictions?, Hydrol. Process., 30, 2014-2032, doi:10.1002/hyp.10749, 2016.

Schumann, G. J.-P., Neal, J. C., Voisin, N., Andreadis, K. M., Pappenberger, F., Phanthuwongpakdee, N., Hall, A. C., and Bates, P. D.: A first large-scale flood inundation forecasting model, Water Resour. Res., 49, 6248-6257, doi:10.1002/wrcr.20521, 2013.

Senatore, A., Mendicino, G., Gochis, D. J., Yu, W., Yates, D. N., and Kunstmann, H.: Fully coupled atmosphere-hydrology simulations for the central Mediterranean: Impact of enhanced hydrological parameterization for short and long time scales, J. Adv. Model. Earth Syst., 7, 1693-1715, doi:10.1002/2015MS000510, 2015.

Simard, M., Pinto, N., Fisher, J. B., and Baccini, A.: Mapping forest canopy height globally with spaceborne lidar, J. Geophys. Res., 116, 1-12, doi:10.1029/2011JG001708, 2011.

Trigg, M. A., Wilson, M. D., Bates, P. D., Horritt, M. S., Alsdorf, D. E., Forsberg, B. R., and Vega, M. C.: Amazon flood wave hydraulics, J. Hydrol., 374, 92-105, doi:10.1016/j.jhydrol.2009.06.004, 2009.

UNISDR: Global Assessment Report on Disaster Risk Reduction, United Nations International Strategy for Disaster Reduction Secretariat, Geneva, Italy, 2011.

Uppala, S. M., KÅllberg, P. W., Simmons, A. J., Andrae, U., Bechtold, V. D. C., Fiorino, M., Gibson, J. K., Haseler, J., Hernandez, A., Kelly, G. A., Li, X., Onogi, K., Saarinen, S., Sokka, N., Allan, R. P., Andersson, E., Arpe, K., Balmaseda, M. A., Beljaars, A. C. M., Van De Berg, L., Bidlot, J., Bormann, N., Caires, S., Chevallier, F., Dethof, A., Dragosavac, M., Fisher, M., Fuentes, M., Hagemann, S., Hólm, E., Hoskins, B. J., Isaksen, L., Janssen, P. A. E. M., Jenne, R., Mcnally, A. P., Mahfouf, J.-F., Morcrette, J.-J., Rayner, N. A., Saunders, R. W., Simon, P., Sterl, A., Trenberth, K. E., Untch, A., Vasiljevic, D., Viterbo, P., and Woollen, J.: The ERA-40 re-analysis, Q. J. Roy. Meteorol. Soc., 131, 2961-3012, doi:10.1256/qj.04.176, 2005.

van Beek, L. P. H.: Forcing PCR-GLOWB with CRU data, Department of Physical Geography, Utrecht University, available at: http://vanbeek.geo.uu.nl/suppinfo/vanbeek2008.pdf (last access: 20 December 2016), 2008.

van Beek, L. P. H. and Bierkens, M. F. P.: The Global Hydrological Model PCR-GLOBWB: Conceptualization, Parameterization and Verification, available at: http://vanbeek.geo.uu. nl/suppinfo/vanbeekbierkens2009.pdf (last access: 20 December 2016), 2008.

van Beek, L. P. H., Wada, Y., and Bierkens, M. F. P.: Global monthly water stress: 1. Water balance and water availability, Water Resour. Res., 47, W07517, doi:10.1029/2010WR009791, 2011.

Visser, H., Bouwman, A., Ligtvoet, W., and Petersen, A. C.: A statistical study of weather-related disasters: past, present and future, PBL Netherlands Environ. Assess. Agency, Hague, Bilthoven, the Netherlands, 2012.

Wagner, S., Fersch, B., Yuan, F., Yu, Z., and Kunstmann, H.: Fully coupled atmospheric-hydrological modeling at regional and long-term scales: Development, application, and analysis of WRF-HMS, Water Resour. Res., 52, 3187-3211, doi:10.1002/2015WR018185, 2016.

Wanders, N. and Wada, Y.: Human and climate impacts on the 21st century hydrological drought, J. Hydrol., 526, 208-220, doi:10.1016/j.jhydrol.2014.10.047, 2015.

Ward, P. J., Jongman, B., Salamon, P., Simpson, A., Bates, P. D., De Groeve, T., Muis, S., de Perez, E. C., Rudari, R., Trigg, M. A., and Winsemius, H. C.: Usefulness and limitations of global flood risk models, Nat. Clim. Change, 5, 712-715, doi:10.1038/nclimate2742, 2015.

Weiland, F. S., van Beek, L. P. H., Kwadijk, J. C. J., and Bierkens, M. F. P.: The ability of a GCM-forced hydrological model to reproduce global discharge variability, Hydrol. Earth Syst. Sci., 14, 1595-1621, doi:10.5194/hess-14-1595-2010, 2010.

Wilson, M. D., Bates, P. D., Alsdorf, D. E., Forsberg, B., Horritt, M., Melack, J., Frappart, F., and Famiglietti, J.: Modeling large-scale inundation of Amazonian seasonally flooded wetlands, Geophys. Res. Lett., 34, 4-9, doi:10.1029/2007GL030156, 2007.

Winsemius, H. C., van Beek, L. P. H., Jongman, B., Ward, P. J., and Bouwman, A.: A framework for global river flood risk assessments, Hydrol. Earth Syst. Sci., 17, 1871-1892, doi:10.5194/hess-17-1871-2013, 2013.

Winsemius, H. C., Aerts, J. C. J. H., van Beek, L. P. H., Bierkens, M. F. P., Bouwman, A., Jongman, B., Kwadijk, J. C. J., Ligtvoet, W., Lucas, P. L., van Vuuren, D. P., and Ward, P. J.: Global Drivers of Future River Flood Risk, Nat. Clim. Change, 6, 381-385, doi:10.1038/NCLIMATE2893, 2016.

Wood, E. F., Lettenmaier, D. P., and Zartarian, V. G.: A landsurface hydrology parameterization with subgrid variability for general circulation models, J. Geophys. Res., 97, 2717, doi:10.1029/91JD01786, 1992.

Wood, E. F., Roundy, J. K., Troy, T. J., van Beek, L. P. H., Bierkens, M. F. P., Blyth, E., de Roo, A., Döll, P., Ek, M., Famiglietti, J., Gochis, D., Van De Giesen, N., Houser, P., Jaffé, P. R., Kollet, S., Lehner, B., Lettenmaier, D. P., Lidard, C. P., Sivapalan, M., Sheffield, J., Wade, A., and Whitehead, P.: Hyperresolution global land surface modeling: Meeting a grand challenge for monitoring Earth's terrestrial water, Water Resour. Res., 47, 110, doi:10.1029/2010WR010090, 2011. 
Yamazaki, D., Kanae, S., Kim, H. and Oki, T.: A physically based description of floodplain inundation dynamics in a global river routing model, Water Resour. Res., 47, 1-21, doi:10.1029/2010WR009726, 2011.

Yamazaki, D., Baugh, C. A., Bates, P. D., Kanae, S., Alsdorf, D. E., and Oki, T.: Adjustment of a spaceborne DEM for use in floodplain hydrodynamic modeling, J. Hydrol., 436-437, 81-91, doi:10.1016/j.jhydrol.2012.02.045, 2012a.

Yamazaki, D., Lee, H., Alsdorf, D. E., Dutra, E., Kim, H., Kanae, S., and Oki, T.: Analysis of the water level dynamics simulate by a global river model: A case study in the Amazon River, Water Resour. Res., 48, 1-15, doi:10.1029/2012WR011869, 2012 b.

Yamazaki, D., O’Loughlin, F., Trigg, M. A., Miller, Z. F., Pavelsky, T. M., and Bates, P. D.: Development of the Global Width Database for Large Rivers, Water Resour. Res., 50, 2108-2123, doi:10.1002/2013WR014664, 2014.

Yamazaki, D., Trigg, M. A. and Ikeshima, D.: Development of a global $\sim 90 \mathrm{~m}$ water body map using multitemporal Landsat images, Remote Sens. Environ., 171, 337-351, doi:10.1016/j.rse.2015.10.014, 2015.
Yoon, Y., Durand, M., Merry, C. J., Clark, E. A., Andreadis, K. M., and Alsdorf, D. E.: Estimating river bathymetry from data assimilation of synthetic SWOT measurements, J. Hydrol., 464, 363-375, doi:10.1016/j.jhydrol.2012.07.028, 2012.

Yossef, N. C., van Beek, L. P. H., Kwadijk, J. C. J., and Bierkens, M. F. P.: Assessment of the potential forecasting skill of a global hydrological model in reproducing the occurrence of monthly flow extremes, Hydrol. Earth Syst. Sci., 16, 4233-4246, doi:10.5194/hess-16-4233-2012, 2012.

Zabel, F. and Mauser, W.: 2-way coupling the hydrological land surface model PROMET with the regional climate model MM5, Hydrol. Earth Syst. Sci., 17, 1705-1714, doi:10.5194/hess-171705-2013, 2013.

Zhao, Q., Ye, B., Ding, Y., Zhang, S., Yi, S., Wang, J., Shangguan, D., Zhao, C., and Han, H.: Coupling a glacier melt model to the Variable Infiltration Capacity (VIC) model for hydrological modeling in north-western China, Environ. Earth Sci., 68, 87-101, doi:10.1007/s12665-012-1718-8, 2013. 